ISSN. 2775-4324 (Online)

Journal of Physical Activity and Sports

Volume 2, Nomor 1, Bulan 2021, 78-87

Journal of Physical Activity and Sports

\title{
SURVEI MINAT MASYARAKAT TERHADAP AKTIVITAS OLAHRAGA REKREASI MASA PANDEMI COVID-19 DI SIMPANG LIMA SEMARANG
}

\author{
Kukuh Aji Prakoso*, Osa Maliki, Buyung Kusumawardhana \\ UNIVERSITAS PGRI SEMARANG. Jln Gajah Raya No 40. 50166 \\ UNIVERSITAS PGRI SEMARANG. Jln Gajah Raya No 40. 50166 \\ UNIVERSITAS PGRI SEMARANG. Jln Gajah Raya No 40. 50166 \\ *Coressponding Author. Email : Akukuh78@gmail.com
}

Received: 18/12/2021; Revised: 22/4/2021; Accepted: 29/4/2021

\begin{abstract}
Recreational sports activities are activities related to physical body movements as a fulfillment of physical needs with the aim of freshness and health. Weekend recreational sports activities at Simpang Lima have developed very rapidly with the increasing number of people. However, during the Covid-19 pandemic, it was suspected that there was a decline in people who took part in recreational sports at the place, so it is necessary to conduct research with the aim of knowing the level of recreational sports activities and the factors that affect recreational sports activities during the Covid-19 pandemic at Simpang Lima Semarang City.

The research approach is quantitative descriptive research. The research location is Simpang Lima Semarang City. The number of samples used is 100 respondents divided into adolescents ( $<20$ years), adults (21-50 years), parents (> 50 years). The data collection methods used in this study were questionnaires, observation and documentation. The data analysis technique uses descriptive percentages.

The results of this study indicate that the level of recreational sports activity carried out during the Covid19 pandemic at Simpang Lima Semarang in 2020 is $85.92 \%$ and is included in the high category and the factors that affect recreational sports activities during the Covid-19 pandemic include physical factors. , psychological factors, family factors, and community environmental factors.
\end{abstract}

Keyword :Semarang City, Simpang Lima, Covid-19 Pandemic, Recreational Sports.

Abstrak

Aktivitas olahraga rekreasi merupakan kegiatan yang berhubungan dengan gerak fisik tubuh sebagai pemenuhan kebutuhan jasmani dengan tujuan kesegaran dan kesehatan. Aktivitas olahraga rekreasi akhir pekan di Simpang Lima terjadi perkembangan sangat pesat dengan semakin meningkatnya jumlah masyarakat. Tetapi pada masa pandemi covid-19 ini diduga terjadi penurunan masyarakat yang melakukan olahraga rekreasi tempat tersebut sehingga perlu dilakukan penelitian dengan tujuan untuk mengetahui tingkat aktivitas olahraga rekreasi dan faktor yang mempengaruhi aktivitas olahraga rekreasi pada masa pandemi covid-19 di Simpang Lima Kota Semarang.

Pendekatan penelitian ini adalah penelitian deskriptif kuantitatif. Lokasi penelitian yaitu Simpang Lima Kota Semarang. Jumlah sampel yang digunakan yaitu 100 responden terbagi atas remaja $(<20$ th), dewasa (2150 th), orangtua ( $>50$ th). Metode pengumpulan data yang digunakan dalam penelitian ini dengan kuisioner, observasi dan dokumentasi. Teknik analisis data menggunakan dekriptif persentase.

Hasil penelitian ini menunjukkan bahwa tingkat aktivitas olahraga rekreasi yang dilakukan pada masa pandemi covid-19 di Simpang Lima Semarang tahun 2020 sebesar 85,92\% dan termasuk dalam kategori tinggi dan faktor yang mempengaruhi aktivitas olahraga rekreasi pada masa pandemi covid-19 antara lain faktor fisik, faktor psikis, faktor keluarga, dan faktor lingkungan masyarakat.

Kata kunci: Kota Semarang, Simpang Lima, Pandemi Covid-19, Olahraga Rekreasi.

\section{PENDAHULUAN}

Kota Semarang memiliki tempat yang digunakan masyarakat untuk mengisi waktu luang di akhir 
pekan yaitu Simpang Lima. Simpang Lima terletak di pusat Kota Semarang yang merupakan pusat aktivitas publik bagi masyarakat Kota Semarang. Simpang Lima merupakan salah satu fasilitas serba guna yang dimiliki oleh Kota Semarang termasuk olahraga rekreasi. Aktivitas olahraga rekreasi akhir pekan di Simpang Lima terjadi perkembangan pesat dengan semakin meningkatnya jumlah masyarakat yang beraktivitas jasmani di tempat tersebut. Tetapi pada saat masa Pandemi Covid-19 ini terjadi penurunan masyarakat yang menghabiskan waktu luang di Simpang Lima tersebut.

Masyarakat melakukan berbagai aktivitas olahraga rekreasi dimasa pandemi covid-19 diantaranya dengan berolahraga, berekreasi dan kegiatan-kegiatan lain yang sifatnya mempertahankan kebugaran jasmani. Dengan mempertahankan kebugaran jasmani, masyarakat memperoleh manfaat sehingga dapat meningkatkan kesehatan. Disaat pandemi covid-19 seperti ini orang yang sering melakukan latihan kebugaran jasmani akan menambah imunitas dan terhindar dari virus dan penyakit. Kebugaran jasmani sangat penting dalam kehidupan sehari-hari agar terhindar dari penyakit yang selalu membayangi kehidupan. Dalam usaha peningkatan kesehatan harus dilakukan latihan jasmani secara teratur dan benar sesuai dengan kondisi tubuh.

Selama pandemi Covid-19, Kota Semarang menerapkan protokol kesehatan dalam kegiatan sehari-hari termasuk aktivitas akhir pekan di kawasan Simpang Lima dan meniadakan car free day untuk mencegah penularan virus. Namun situasi kesadaran masyarakat dalam menerapkan protokol kesehatan di kawasan Simpang Lima Semarang selama masa new normal menurun. Hal ini terlihat dari masih adanya masyarakat yang datang ke kawasan Simpang Lima Semarang untuk melakukan aktivias olahraga.

Berdasarkan latar belakang tersebut di atas, maka disimpulkan bahwa aktivitas olahraga rekreasi akhir pekan merupakan kegiatan yang berhubungan dengan gerak fisik tubuh sebagai pemenuhan kebutuhan jasmani dengan tujuan kesegaran dan kesehatan sehingga perlu dilakukan penelitian dengan judul "Survei Minat Masyarakat terhadap Aktivitas Olahraga Rekreasi pada Masa Pandemi Covid-19 Di Simpang Lima Kota Semarang Tahun 2020 ”.

\section{METODE}

Metode penelitian adalah cara yang digunakan oleh peneliti dalam mengumpulkan data penelitiannya. Metode penelitian juga sering disebut sebagai cara atau langkah-langkah yang digunakan untuk memperoleh pengetahuan dengan menggunakan prosedur yang reliabel dan terpercaya.

\section{Desain Penelitian}

Penelitian ini termasuk penelitian deskriptif dengan menggunakan desain metode survei. Penelitian deskriptif adalah penelitian yang dimaksudkan untuk menyelidiki keadaan, kondisi atau hal-hal lain yang sudah disebutkan, yang hasilnya dipaparkan dalam bentuk laporan penelitian (Arikunto, 2010: 3). 


\section{Populasi dan Sampel Penelitian}

Populasi dalam penelitian ini adalah seluruh masyarakat Kota Semarang yang melakukan kegiatan olahraga rekreasi pada masa pandemi Covid-19 di Simpang Lima Kota Semarang. Teknik pengambilan sampel dalam penelitian ini menggunakan teknik random sampling, dengan jumlah total populasi yang ada adalah seluruh masyrakat yang dalam olahraga rekreasi di Simpang Lima.

Menurut Arikunto (2010:174), sampel adalah sebagian atau wakil dari populasi yang akan diteliti. Bila populasi besar dan peneliti tidak memungkinkan mempelajari semua yang ada pada populasi karena keterbatasan dana, tenaga dan waktu, maka peneliti dapat menggunakan sampel dari data yang diambil dari populasi itu. Berdasarkan acuan tersebut pengambilan sampel untuk memperoleh datanya dengan teknik sampling insidental, yaitu teknik penentuan sampel berdasarkan kebetulan, yaitu siapa saja yang secara kebetulan/insidental bertemu dengan peneliti dapat digunakan sebagai sampel, bila dipandang orang yang kebetulan ditemui itu cocok sebagai sumber data (Sugiyono, 2013: 67). Artinya masyarakat yang berkunjung yang dijadikan sampel yang kebetulan bertemu di lokasi penelitian pada saat pencarian data berjumlah 100 responden.

\section{Definisi Variabel}

Variabel penelitian adalah segala sesuatu yang berbentuk apa saja yang ditetapkan oleh peneliti untuk dipelajari sehingga diperoleh informasi tentang hal tersebut, kemudian ditarik kesimpulan (Sugiyono, 2013:38). Variabel yang dimaksud dalam penelitian ini yaitu survei olahraga rekreasi pada masa pandemi Covid-19 di Simpang Lima Kota Semarang tahun 2020. Faktor yang akan diteliti meliputi faktor internal (faktor kondisi fisik dan kondisi psikis) dan eksternal (lingkungan keluarga, lingkungan pekerjaan dan lingkungan masyarakat) aktivitas olahraga rekreasi pada masa pandemi Covid-19 di Simpang Lima Kota Semarang tahun 2020. Mengungkap variable minat dimaksudkan sebagai batasan yang dijadikan pegangan dalam mengungkap gejala yang ingin diteliti. Definisi operasional minat adalah perasaan senang atau tertarik yang dimiliki oleh seseorang yang menebabkan orang tersebut memusatkan perhatiannya kepada suatu objek tertentu.

\section{Metode Pengumpulan Data}

\section{Angket}

Dalam penelitian ini instrumen yang digunakan adalah dengan angket/kuisioner. Angket atau kuesioner merupakan metode pengumpulan data yang dilakukan dengan cara memberi seperangkat pernyataan atau pertanyaan tertulis kepada responden untuk diberikan respon sesuai dengan permintaan pengguna (Widoyoko, 2016: 33). Menurut Sugiyono (2013: 199) kuesioner merupakan teknik pengumpulan data yang dilakukan dengan cara memberi seperangkat pertanyaan atau pernyataan tertulis kepada responden untuk dijawab.

Adapaun angket yang digunakan dalam penelitian ini berupa angket tertutup. Dimana dalam angket tertutup ini pertanyaan atau pernyataan telah disediakan jawabnya sehingga responden hanya tinggal memilih jawaban yang telah tersedia. 
Angket dalam penelitian ini adalah dalam bentuk skala. Skala adalah alat untuk mengukur nilai, sikap, minat, perhatian, motivasi yang disusun dalam bentuk pernyataan untuk dinilai responden dan hasilnya dalam bentuk rentangan nilai angka sesuai dengan criteria yang dibuat peneliti. Skala yang digunakan dalam penelitian ini adalah skala yang digunakan untuk mengukur sikap seseorang terhadap objek tertentu (skala Likert dengan lima skala Likert).

\section{Dokumentasi}

Metode dokumentasi adalah salah satu metode pengumpulan data kualitatif dengan melihat atau menganalisis dokumen-dokumen yang dibuat oleh subjek sendiri atau oleh orang lain oleh subjek. Dokumentasi merupakan salah satu cara yang dapat dilakukan peneliti kualitatif untuk mendapatkan gambaran dari sudut pandang subjek melalui suatu media tertulis dan dokumen lainnya yang ditulis atau dibuat langsung oleh subjek yang bersangkutan. Dalam penelitian ini metode dokumentasi untuk memperoleh data mengenai hal-hal yang berupa catatan, transkrip, buku, surat kabar, notulen, dan sebagainya. Dari penelitian yang telah dilakukan ada beberapa dokumentasi yang telah di ambil oleh penulis sebagai refrensi dan penguat data di lapangan diantaranya adalah koleksi dokumentasi foto suasana kegiatan olahraga yang sedang berlangsung dengan berbagai acara di dalamnya dari minggu per minggu.

\section{Observasi}

Metode observasi adalah pengamatan dan pencatatan secara sistematik unsur-unsur yang tampak dalam suatu gejala pada objek penelitian. Menurut Morris dalam Syamsudin (2014:404), observasi merupakan aktifitas mencatat suatu gejala atau peristiwa dengan bantuan alat atau instrumen untuk merekam atau mencatatnya guna tujuan ilmiah atau tujuan lainnya. Observasi yang akan dilakukan adalah di area Simpang lima sampai di Jalan Pahlawan.

Dalam penelitian ini, peneliti menggunakan observasi berperan serta (participan to observation), yaitu peneliti terlibat dengan kegiatan sehari-hari orang yang sedang diamati. Dengan observasi partisipan, maka data yang diperoleh akan lebih lengkap, tajam, dan sampai mengetahui pada tingkat makna dari setiap perilaku yang nampak.

\section{Instrumen Penelitian}

Instrumen yang sudah jadi tidak langsung dijadikan untuk mengambil data, tetapi instrumen itu harus diuji cobakan dulu pada sampel uji coba untuk mendapatkan instrumen yang dapat di pertanggungjawabkan. Untuk mengetahui apakah instrumen yang disusun sudah valid atau tidak dan untuk mengetahui kualitas tingkat instrumen perlu di ukur validitas dan reabilitas instrumen, sehingga instrumen tersebut dapat menjaring atau mengungkap data yang dibutuhkan untuk menjawab permasalahan penelitian sesuai dengan yang dirumuskan sebelumnya.

\section{Validitas dan Reabilitas Instrumen}

\section{Uji Validitas}


Validitas adalah suatu ukuran yang menunjukkan tingkat-tingkat ketelitian suatu instrument. Sebuah instrumen dikatakan memiliki validitas jika hasilnya sesuai dengan kriteria. Sebuah instrumen dikatakan valid apabila instrumen tersebut mengukur apa yang hendak diukur dan dalam bahasa indonesia "valid" disebut istilah "salih". Sebenarnya pembicaraan tentang validitas ini bukan ditemukan pada tes itu sendiri tetapi pada hasil pengetesan atau skornya (Arikunto, 2010: 80). Perhitungan uji validitas akan dilakukan dengan bantuan computer program SPSS (Statistical for Social Science) versi 19.

Setelah melaksanakan ujicoba pada responden berjumlah 69 orang dan dilakukan perhitungan uji validitas item pernyataan yang tidak valid sebanyak 3 item yaitu item nomor 11, 13 dan 16. Adapun item pernyataan yang tidak valid tersebut akan dihilangkan sehingga jumlah item pertanyaan yang akan digunakan dalam penelitian sebanyak 32 item.

\section{Uji Reliabilitas}

Sugiyono (2013: 173) menyatakan bahwa instrumen yang reliabilitas adalah instrumen yang bila digunakan beberapa kali untuk mengukur obyek yang sama hasilnya akan sama walaupun digunakan dalam waktu yang berbeda. Dalam penelitian ini, untuk menghitung reliabilitas instrumen adalah dengan teknik Alpha Cronbach. Untuk mengetahui apakah kuesioner tersebut sudah reliabel dilakukan pengujian reliabilitas kuesioner dengan bantuan computer program SPSS.

Berdasarkan perhitungan reliabilitas menggunakan program SPSS diperoleh hasil reliabilitas sebesar 0,910 dimana nilai tersebut lebih besar dari 0,6. Oleh karena itu, instrumen penelitian dinyatakan reliabel dikarenakan $0,910>0,6$.

\section{Analisis Data}

\section{Tinjauan Metode Analisis}

Metode ini digunakan untuk mengetahui sejauh mana aktivitas olahraga rekreasi pada masa pandemi Covid-19 di Simpang Lima Semarang Tahun 2020. Metode analisis data yang digunakan dalam penelitian ini adalah pendekatan kuantitatif yang bersifat deskriptif persentase. Metode analisis data yang digunakan dalam penelitian ini adalah analisis deskriptif persentase.

Dalam penelitian ini menggunakan pendekatan bersifat kuantitatif yang merupakan proses penggambaran penelitian. Dalam penelitian ini akan digambarkan tentang survei aktivitas olahraga rekreasi pada masa pandemi Covid-19 di Simpang Lima Semarang Tahun 2020.

Analisis deskriptif yang digunakan adalah analisis deskriptif prosentase. Dalam analisis ini semua skor dari masing-masing aspek dijumlahkan dan dibandingkan dengan skor idealnya sehingga akan diperoleh prosentase skor. Dari deskriptif prosentase inilah selanjutnya dibandingkan dengan kritreria yang digunakan dan dan diketahui tingkatanya. Karena skor tertinggi dari masing-masing skor adalah 5 dan skor terendahnya adalah 1 maka dapat dihitung; 


\section{HASIL DAN PEMBAHASAN}

\section{Deskripsi Umum Objek Penelitian}

Penelitian ini dilaksanakan di Simpang Lima Kota Semarang mengenai minat masyarakat dalam melakukan olahraga rekreasi selama masa pandemi covid-19 tahun 2020. Penyebaran angket yang diberikan kepada responden dilakukan di Simpang Lima Kota Semarang yang dilaksanakan pada bulan November 2020. Dalam hal ini peneliti menggunakan teknik pengambilan data yaitu purposive sampling dimana saat pengambilan data sudah ditentukan lokasinya yaitu di Simpang Lima Kota Semarang.

\section{Hasil Penelitian}

\section{Deskripsi Responden}

a. Karakteristik Responden berdasarkan Jenis Kelamin

Tabel 1. Distribusi Frekuensi Responden Berdasarkan Jenis Kelamin

\begin{tabular}{llcc}
\hline No & Jenis kelamin & Frekuensi & Persentase $(\%)$ \\
\hline 1 & Laki-laki & 42 & 42 \\
2 & Perempuan & 58 & 58 \\
\hline \multicolumn{2}{l}{ Jumlah } & 100 & 100 \\
\hline
\end{tabular}

b. Karakteristik Responden berdasarkan Usia

Tabel 2. Distribusi Frekuensi Responden Berdasarkan Usia

\begin{tabular}{llcc}
\hline No & Usia & Frekuensi & Persentase $(\%)$ \\
\hline 1 & Remaja $(<20$ tahun) & 26 & 26 \\
2 & Dewasa ( 21 -50 tahun) & 72 & 72 \\
3 & Tua (> 50 tahun & 2 & 2 \\
\hline Jumlah & 100 & 100 \\
\hline
\end{tabular}

\section{Aktivitas Olahraga Rekreasi}

Tabel 3. Tingkat Minat Masyarakat terhadap Aktivitas Olahraga Rekreasi

\begin{tabular}{lllcc}
\hline No & Interval Persentase & Kriteria & Frekuensi & Persentase $(\%)$ \\
\hline 1 & $77,8 \%-100 \%$ & Tinggi & 88 & 88 \\
2 & $55,6 \%-77,8 \%$ & Sedang & 12 & 12 \\
3 & $33,3 \%-53,6 \%$ & Rendah & 0 & 0 \\
\hline Jumlah & & 100 & 100 \\
Rata-rata persentase & & \multicolumn{3}{c}{85,92} \\
Kriteria & & \multicolumn{3}{c}{ Tinggi } \\
\hline
\end{tabular}

Sumber: Analisis Hasil Penelitian 2020

\section{Faktor Minat Masyarakat terhadap Aktivitas Olahraga Rekreasi}

Faktor-faktor yang mempengaruhi tingkat minat masyarakat terhadap aktivitas olahraga rekreasi dalam penelitian ini ada 4 yang dikaji yaitu faktor fisik, faktor psikis, faktor keluarga, dan faktor masyarakat.

a. Faktor fisik 
Tabel 4. Faktor Fisik

\begin{tabular}{lllcc}
\hline No & Interval persentase & Kriteria & Frekuensi & Persentase (\%) \\
\hline 1 & $77,8 \%-100 \%$ & Tinggi & 93 & 93 \\
2 & $55,6 \%-77,8 \%$ & Sedang & 7 & 7 \\
3 & $33,3 \%-53,6 \%$ & Rendah & 0 & 0 \\
\hline Jumlah & & 100 & 100 \\
Rata-rata persentase & & \multicolumn{2}{c}{88,36} \\
Kriteria & & Tinggi & \\
\hline
\end{tabular}

b. Faktor psikis

Tabel 5. Faktor Psikis

\begin{tabular}{lllcc}
\hline No & Interval persentase & Kriteria & Frekuensi & Persentase (\%) \\
\hline 1 & $77,8 \%-100 \%$ & Tinggi & 72 & 72 \\
2 & $55,6 \%-77,8 \%$ & Sedang & 27 & 27 \\
3 & $33,3 \%-53,6 \%$ & Rendah & 1 & 1 \\
\hline Jumlah & & 100 & 100 \\
Rata-rata persentase & & \multicolumn{2}{c}{79,5} \\
Kriteria & & \multicolumn{2}{c}{ Tinggi } \\
\hline
\end{tabular}

c. Faktor keluarga

Tabel 6. Faktor Keluarga

\begin{tabular}{lllcc}
\hline No & Interval persentase & Kriteria & Frekuensi & Persentase (\%) \\
\hline 1 & $77,8 \%-100 \%$ & Tinggi & 73 & 73 \\
2 & $55,6 \%-77,8 \%$ & Sedang & 27 & 27 \\
3 & $33,3 \%-53,6 \%$ & Rendah & 0 & 0 \\
\hline \multicolumn{2}{l}{ Jumlah } & & 100 & 100 \\
Rata-rata persentase & & \multicolumn{2}{c}{79,72} \\
\multicolumn{2}{l}{ Kriteria } & & Tinggi & \\
\hline
\end{tabular}

\section{d. Faktor masyarakat}

Tabel 7. Faktor Masyarakat

\begin{tabular}{lllcc}
\hline No & Interval persentase & Kriteria & Frekuensi & Persentase (\%) \\
\hline 1 & $77,8 \%-100 \%$ & Tinggi & 75 & 75 \\
2 & $55,6 \%-77,8 \%$ & Sedang & 24 & 24 \\
3 & $33,3 \%-53,6 \%$ & Rendah & 1 & 1 \\
\hline Jumlah & & 100 & 100 \\
Rata-rata persentase & & \multicolumn{2}{c}{81,25} \\
Kriteria & & Tinggi \\
\hline
\end{tabular}

\section{Pembahasan}

\section{Tingkat Minat Masyarakat terhadap Aktivitas Olahraga Rekreasi}

Berdasarkan hasil penelitian diketahui bahwa tingkat minat masyarakat terhadap aktivitas olahraga rekreasi di masa pandemi covid-19 di simpang lima semarang tergolong tinggi. Olahraga di masa pandemi sangat dibutuhkan untuk menjadikan kebiasaan hidup yang sehat dengan berolahraga. Selain itu, masyarakat tetap beraktivitas olahraga rekreasi ini agar mendapat kesehatan yang maksimal dalam menghadapi pandemi ini. Olahraga sudah menjadi kegiatan yang harus dilakukan minimal 
seminggu sekali yaitu diakhir pekan. Hal ini dilakukan agar kelelahan dalam bekerja hilang dan di awal minggu depan dapat bekerja secara maksimal kembali.

Olahraga rekreasi yang dilakukan masyarakat diakhir pekan di area simpang lima merupakan salah satu cara untuk mengistirahatkan tubuh yang sebelumnya bekerja. Istirahat sangat diperlukan agar tubuh memiliki kesempatan melakukan recovery (pemulihan) sehingga dapat melakukan kerja atau aktivitas sehari-hari dengan nyaman. Kelelahan dalam pekerjaan adalah salah satu keterbatasan fungsi tubuh manusia. Atas dasar tersebut maka diperlukan olahraga rekreasi untuk menghilangkan rasa lelah tersebut.

Hasil penelitian ini sejalan dengan hasil penelitian yang dilakukan oleh Mylsidayu dan Pratama (2016) dengan judul "Survei Minat Masyarakat Terhadap Olahraga Di Wilayah Marunda Baru Jakarta Utara”. Hasil penelitian tersebut menunjukan bahwa tingkat minat masyarakat terhadap aktivitas olahraga tergolong tinggi yaitu mencapai 51,6\%. Hasil Penelitian yang dilakukan oleh Indricha (2019) dengan judul "Survei Minat Olahraga Pengunjung Car Free Day Boulevard Makassar". Hasil ini juga menunjukan bahwa pengunjung yang minat dengan kategori tinggi ada sebanyak 57\%.

\section{Faktor yang Mempengaruhi Olahraga Rekreasi}

Berdasarkan hasil penelitian diketahui bahwa faktor-faktor yang mempengaruhi tingkat minat masyarakat terhadap aktivitas olahraga rekreasi di masa pandemi covid-19 di simpang lima semarang antara lain faktor fisik, faktor psikis, faktor keluarga dan faktor masyarakat. Hasil penelitin menunjukkan bahwa semua faktor tersebut termasuk kategori tinggi secara rata-rata dalam mempengaruhi aktivitas olahraga rekreasi.

Faktor fisik berdasarkan hasil penelitian di atas termasuk kategori tinggi. Faktor fisik rata-rata diperoleh $88,36 \%$ dalam mempengaruhi tingkat minat masyarakat terhadap aktivitas olahraga rekreasi. Faktor fisik ini meliputi kondisi kesehatan yaitu sehat berarti dalam keadaan baik segenap badan beserta bagian-bagiannya atau bebas dari penyakit. Kesehatan manusia berpengaruh terhadap aktivitas yang meraka pilih. Cacat tubuh adalah sesuatu yang menyebabkan kurang baik atau kurang sempurna mengenai tubuh atau badan. Cacat itu dapat berupa buta, setengah tuli, tuli, patah kaki, dan patah tangan, lumpuh dan lain-lain. Keadaan cacat tubuh juga mempengaruhi aktivitas, apalagi jenis olahraga yang membutuhkan badan yang normal karena memerlukan kondisi dan stamina yang normal.

Faktor psikis dari hasil penelitian menunjukkan bahwa faktor tersebut tergolong tinggi. Responden melakukan olahraga setiap diakhir pekan dengan tujuan menghilangkan stress kerja sebelumnya. Remaja yang aktif dalam berolahraga, penyimpangan perilakunya sangat kecil dibandingkan remaja yang tidak berpartisipasi dalam olahraga. Olahraga merupakan salah satu alternatif yang dapat digunakan sebagai alat pembentukan karakter manusia. Melalui olahraga seseorang akan memiliki rasa tanggungjawab, rasa hormat dan memiliki kepedulian terhadap sesama.

Faktor keluarga dari hasil penelitian menunjukkan termasuk kriteria tinggi. Rekreasi dengan anggota keluarga akan menjadikan keluarga harmonis. Lingkungan keluarga sebagai lingkungan 
pendidikan yang pertama sangat penting dalam membentuk pola kepribadian anak karena dalam keluarga anak pertama kali berkenalan dengan nilai norma. Membangun anak dalam kontek individu diarahkan agar anak dapat mengembangkan dan menolong dirinya sendiri. Dalam kontek ini anak cenderung untuk menciptakan kondisi yang dapat menumbuh kembangkan inisiatif, kreatifitas, kehendak, emosi, tanggung jawab, ketrampilan, minat dan kegiatan lain yang sesuai kondisi di dalam keluarga.

Faktor masyarakat merupakan semua hubungan diluar rumah dan pekerjaan. Lingkungan tempat tinggal sangat berpengaruh terhadap minat olahraga rekreasi akhir pekan. Berolahraga dengan relasi kerja akan menimbulkan rasa percaya kepada relasi dalam pekerjaan. Dimasa Pandemi Covid-19 Olahraga menjadi trend dikalangan masyarakat. salah satu alasan mengikuti aktivitas olahraga rekreasi di simpang lima yaitu dengan Aktivitas olahraga akan menjadikan beban pekerjaan menjadi ringan.

\section{KESIMPULAN DAN SARAN}

\section{Kesimpulan}

Berdasarkan hasil penelitian dan pembahasan di atas maka kesimpulan dalam penelitian ini adalah tingkat minat masyarakat terhadap aktivitas olahraga rekreasi yang dilakukan pada masa Pandemi Covid-19 di Simpang Lima Semarang tahun 2020 sebesar 85,92\% termasuk kategori tinggi.

Faktor yang mempengaruhi minat masyarakat terhadap aktivitas olahraga rekreasi pada masa Pandemi Covid-19 di Simpang Lima tahun 2020 antara lain faktor fisik, faktor psikis, faktor keluarga, dan faktor lingkungan masyarakat.

\section{Saran}

Saran yang dapat diberikan dari penelitian ini adalah bagi responden di masa pandemi tetap taat pada protokol kesehatan yang berlaku, bagi keluarga agar memberikan dukungan yang baik agar mengikuti olahraga rekreasi karena faktor keluarga menjadi faktor yang paling berpengaruh terhadap seseorang dalam beraktivitas olahraga rekreasi dan saran bagi pengelola Simpang lima Kota Semarang untuk senantiasa meningkatkan kualitas kegiatan dengan cara memanfaatkan sekecil apapun potensi setiap instansi yang ingin berpartisipasi.

\section{DAFTAR PUSTAKA (Gunakan Microsoft Word template style: Heading 1)}

Arikunto, S. 2010. Prosedur Penelitian Suatu Pendekatan Praktek. Jakarta: Rineka Cipta.

Armi, D., Mansur dan M. Nusufi. 2015. Partisipasi Orang Tua terhadap Minat Anak Berolahraga di kecamatan Singkil Kabupaten Aceh Singkil. Jurnal Ilmiah Mahasiswa Pendidikan Jasmani, Kesehatan, dan Rekreasi Fakultas Keguruan dan Ilmu Pendidikan Unsyiah. 1(4): 258-271. 
Dimyati, R. W. M. 2013. Pengaruh Implementasi Kebijakan Otonomi Daerah dan Dukungan Dana Terhadap Pemberdayaan Olahraga Rekreasi di Kabupaten Tasikmalaya. Jurnal Ilmiah Mahasiswa Pascasarjana Administrasi Pendidikan. 1(2): 199-210.

Griwijoyo, S dan D. Z. Sidik. 2013. Ilmu Kesehatan Olahraga. Bandung: PT Remaja Rosdakarya

Hernawan. 2017. Model Kegiatan Outdoor Games Activities untuk Mahasiswa Program Studi Olahraga Rekreasi Fakultas Ilmu Keolahragaan Universitas Negeri Jakarta. Gladi Jurnal Ilmu Keolahragaan, Vol. 8 (1): 14-36.

Husdarta. 2010. Sejarah dan Filsafat Olahraga. Bandung: Alfabeta.

Indricha, M. 2019. Survei Minat Olahraga Pengunjung Car Free Day Boulevard Makassar. Jurnal Universitas Negeri Makassar. 1(1):1-19.

Kusuma, B. A dan H. Setyawati. 2016. Survei Faktor-Faktor yang Mempengaruhi Minat Olahraga Rekreasi Akhir Pekan di Alun-Alun Wonosobo. Journal of Physical Education, Sport, Health and Recreation. 5(2): 67-73.

Muhadir. 2019. Survei Minat Berolahraga Masyarakat Kota Makassar di Taman Pakui Sayang. Skripsi. Jurusan Pendidikan Jasmani Kesehatan dan Rekreasi Fakultas Ilmu Keolahragaan. Universitas Negeri Makassar.

Mustofa, A dan P. Roniwijaya. 2014. The Effect of Industrial Work Performance Practice and Performance Automotive Electrical Prakti entrepreneurial $n$ Against Interests Automotive Mechanics Class XII SMK Diponegoro Depok Sleman. Jurnal Taman Vokasi. 1(2): 206-214.

Mylsidayu, A. 2014. Psikologi Olahraga. Jakarta: Bumi Aksara.

Mylsidayu, A dan R. V. Pratama. 2016. Survei Minat Masyarakat terhadap Olahraga di Wilayah Marunda Baru Jakarta Utara. Prosiding Seminar Nasional Keolahragaan Universitas Negeri Yogyakarta. ISBN 978-602-8429-72-6. 363-374.

Sugiyono. 2013. Metode Penelitian Kuantitatif, Kualitatif dan R\&D. Bandung: Afabeta.

Syamsudin, A. 2014. Pengembangan Instrumen Evaluasi Non Tes (Informal) untuk Menjaring Data Kualitatif Perkembangan Anak Usia Dini. Jurnal Pendidikan Anak. 3(1): 403-413.

Widoyoko, E. 2016. Penilaian Hasil Pembelajaran di Sekolah. Yogyakarta: Pustaka Pelajar. 